\title{
Existing Management Practices of Buffaloes Owners in Udaipur District of Rajasthan, India
}

\author{
Parsant Jatolia $^{1}$, Suresh Chandra Jingar ${ }^{2 *}$, Shiv Murat Meena ${ }^{3}$, \\ Pankaj Lawania $^{4}$, H.L. Bugaliya ${ }^{5}$ and Deelip Kumar ${ }^{6}$ \\ ${ }^{1}$ Agriculture Department, Chittorgarh, India \\ ${ }^{2}$ A.H., KVK, Chittorgarh, Rajasthan, India \\ ${ }^{3}$ A.H., KVK, Dholpur, Rajasthan, India \\ ${ }^{4}$ A.H., KVK Jalore, Rajasthan, India \\ ${ }^{5}$ A.H., KVK, Banswara, Rajasthan, India \\ ${ }^{6}$ A.H., KVK, Sirohi, Rajasthan, India \\ *Corresponding author
}

A B S T R A C T

\begin{tabular}{|c|}
\hline Keywords \\
\hline $\begin{array}{l}\text { Dairy owners, } \\
\text { Feeding, Housing, } \\
\text { Management, } \\
\text { Buffaloes. }\end{array}$ \\
\hline Article Info \\
\hline $\begin{array}{l}\text { Accepted: } \\
\text { 19 June } 2017 \\
\text { Available Online: } \\
\text { 10 August } 2017\end{array}$ \\
\hline
\end{tabular}

A field survey was conducted to collect the relevant information on buffaloes managemental practices followed by 3932 responded in 22 villages of Udaipur district of Rajasthan. Closed type of house was provided by $48.50 \%$ of the framers. Kaccha type of roof and floor were observed in $92.20 \%$ and $96.77 \%$ of the houses, respectively. Provision of urine drainage facility was found only in $1.01 \%$ and well ventilation found $87.82 \%$ of animal shed. Majority of farmers provided green fodder to their buffaloes. None of the farmers practiced silage making. Concentrates was fed to the buffaloes at the time of milking only. Feeding of mineral mixture was provided by only $31 \%$ of the farmers to their buffaloes.

\section{Introduction}

India has one of the largest livestock population in the world, accounting 56 percent of the world buffalo population and 16 percent cattle population $\left(18^{\text {th }}\right.$ Livestock Census). Buffaloes play a critical role in the intensification of agriculture in farming system. The animals ensure the farmers socioeconomic security. Therefore, proper housing along with feeding management practices play a very significant role in exploiting real potentials of dairy animals (Sinha et al., 2009). Proper housing reduces the energy wastage in maintaining thermo neutral zone as well as reduces the incidence of diseases. It is generally agreed that an animal fail to prove its potential for higher production when fed at low levels.

A livestock management practice followed by the farmers is crucial to identify the strengths and poor animal rearing system and to advise appropriate intervention policies. The present study was undertaken together information regarding to existing housing and feeding 
practices adopted by the farmers of different villages of Udaipur district of Rajasthan.

\section{Materials and Methods}

The field survey was conducted on 3942 farmers to collect the information related to management and feeding practices in 22 villages of Udaipur district of Rajasthan. In all villages surveyed more than $80 \%$ farmers were keeping buffaloes in 6 villages and 50$80 \%$ in 10 villages depleting that majority of the farmers in villages kept buffaloes. The selected farmers were interviewed and collect the desired information with help of pretested questionnaire.

\section{Results and Discussion}

The management practices of housing and feeding followed by all the farmers were studied and each of these practices has been described in following sub-section.

\section{Housing management practices}

The perusal of the results revealed that majority $(66.33 \%)$ of the farmers kept their animals during night time followed by housing during day $(33.62 \%)$. The most of the farmers $(51.50 \%)$ had open type and rest of the farmers closed type animal house. Among the all respondents $92.20 \%$ farmers had kuccha type of roof for their animal housing. These houses are mainly made up of locally available material like bamboo, forest wood, plastered with mud mixed with cow dung. Similar finding was reported by many researchers (Sahu, 2001; Bainwal et al., 2007; Kalyankar et al., 2008).

As for as location of shed is concerned, 56.87 percent owners kept their animal near or part of residence as compared to separate houses $(43.13 \%)$. Purpose of keeping animals near to residence area would be to save cost of constructions of house as income becomes a limiting factor to spend anything on animal housing. Majority of the respondents kept kuccha $(96.77 \%)$ floor in their shed and only $19.76 \%$ had provision of urine drainage facility. These findings are in closed conformity with the results of Kumar et al., (2006). Farmers had the belief that animal feel comfortable on kuccha floor during standing and sitting. The rest of animal houses i.e. $3.23 \%$ have pucca floor. Further reported by Patel et al., (2005), Choudhary et al., (2006) in North Gujrat and Singh et al., (2007 b) in Rajasthan in their survey observed that most of the animal houses had kuccha floor. It is general observation that pucca floor is better than earthen floor for animals to keep them free from worms problems and also from hygienic point of view. The farmers under these study showed awareness is less about these problems and mainly they gave preference to earthen floor, as it remained cheap and comfortable to animals. The majority of animal houses kuccah roof, which might be due to easy availability of material locally and also might be influenced by traditional practices. Peculiarity in roof type found was special type designed to suit the heavy rainfall in Udaipur of Rajasthan state. Similar finding was reported by Singh et al., (2007 b) in their survey region.

Pucca drainage facility of urine was found in only $1.01 \%$ of animals shed, while remaining 98.99 percent had no drainage facility and urine soaked by earthen floor of animal shed as given in table 1 . The result is in agreement with the findings of Patel et al., (2006), Choudhary et al., (2006) and Bainwal et al., (2007) but their respondents showed slightly higher number in providing pucca drain. Contrary to this Modi (2003) reported very high $(82 \%)$ of respondents provided pucca drain. This shows the degree of awareness of dairy owners of Sabarkantha district. 
To protect the animals from extreme weather i.e. sever cold and hot by making a half height of boundary wall $(65.29 \%)$ and with good ventilation $(87.82 \%)$. This shows that farmers are aware to protecting their animals against inclement weather.

\section{Feeding management practices}

Lucerne was the main green fodder about $85.43 \%$ of respondents for feeding to buffaloes followed by $11.24 \%$ farmers not to fed cultivated green fodder to their animals. Majority of respondents growing legume fodders as compared to non-legumes. Green fodder feeding by the respondents in the present study area is higher. Similar finding was also reported by Swaroop and Prasad (2007). It may be due to the availability of more irrigation facility in the study area. Not a single farmer practiced for silage making because of lack of knowledge. Around $56.80 \%$ of farmers fed their buffaloes mixed type dry fodder and rest of jowar (24.21\%) and maize karbi (11.47\%).

Our results (Table 2) indicated that majority $(57.25 \%)$ of the respondents have not practiced for feeding grain and rest of used grain in concentrate mixture for feeding. Among these respondents majority of farmers fed barley $(34.41 \%)$ to their animals followed by maize, jowar, mixed and wheat.

Table.1 Housing management practices followed by dairy owners

\begin{tabular}{|c|c|c|}
\hline Categories & Frequency & Percent \\
\hline \multicolumn{3}{|l|}{ Housing during } \\
\hline Day & 1322 & 33.62 \\
\hline Night & 2608 & 66.33 \\
\hline Both (Day \& Night) & 2 & 0.05 \\
\hline \multicolumn{3}{|l|}{ Type of house } \\
\hline Open & 2025 & 51.50 \\
\hline Closed & 1907 & 48.50 \\
\hline \multicolumn{3}{|l|}{ Type of roof } \\
\hline Kuccha & 3662 & 92.20 \\
\hline Pucca & 308 & 7.80 \\
\hline \multicolumn{3}{|l|}{ Isolation } \\
\hline Separate & 1695 & 43.13 \\
\hline Part of residence & 2335 & 56.87 \\
\hline \multicolumn{3}{|l|}{ Type of Floor } \\
\hline Kuccha & 3803 & 96.77 \\
\hline Pucca & 127 & 3.23 \\
\hline \multicolumn{3}{|l|}{ Boundary wall height } \\
\hline Full & 1252 & 31.87 \\
\hline Half & 2566 & 65.29 \\
\hline Biological fencing & 122 & 2.84 \\
\hline \multicolumn{3}{|l|}{ Sanitary condition of shed } \\
\hline Good & 777 & 19.76 \\
\hline Poor & 3155 & 80.24 \\
\hline \multicolumn{3}{|l|}{ Provision of urine drain } \\
\hline Yes & 40 & 1.01 \\
\hline No & 3892 & 98.99 \\
\hline \multicolumn{3}{|l|}{ Well ventilated } \\
\hline Yes & 3453 & 87.82 \\
\hline No & 479 & 12.18 \\
\hline
\end{tabular}


Table.2 Feeding management practices followed by dairy owners

\begin{tabular}{|c|c|c|}
\hline Categories & Frequency & Percent \\
\hline \multicolumn{3}{|l|}{ Green fodder availability } \\
\hline Lucerne & 3359 & 85.43 \\
\hline Berseem & 29 & 0.73 \\
\hline Jowar & 00 & 00.00 \\
\hline Lucerne + Berseem & 102 & 2.60 \\
\hline Berseem + Jowar & 00 & 00.00 \\
\hline Not to fed & 442 & 11.24 \\
\hline \multicolumn{3}{|l|}{ Dry fodder availability } \\
\hline Jowarkarbi & 952 & 24.21 \\
\hline Bhusa & 147 & 3.73 \\
\hline Maize karbi & 451 & 11.47 \\
\hline Local grass & 149 & 3.80 \\
\hline Mixed & 2233 & 56.80 \\
\hline \multicolumn{3}{|l|}{$\begin{array}{c}\text { Concentrate feeding } \\
\text { Seed grain }\end{array}$} \\
\hline Barley & 1353 & 34.41 \\
\hline Maize & 204 & 5.20 \\
\hline Jowar & 79 & 2.01 \\
\hline Wheat & 22 & 0.55 \\
\hline Mixed & 23 & 0.58 \\
\hline None & 2251 & 57.25 \\
\hline \multicolumn{3}{|l|}{ Cakes } \\
\hline GNC & 74 & 1.88 \\
\hline Mustard & 279 & 7.09 \\
\hline Cotton seed & 63 & 1.60 \\
\hline Till & 47 & 1.19 \\
\hline None & 3469 & 88.22 \\
\hline \multicolumn{3}{|l|}{ Oil seed } \\
\hline Yes & 3149 & 80.09 \\
\hline No & 783 & 19.91 \\
\hline \multicolumn{3}{|l|}{ Readymade feed } \\
\hline Yes & 964 & 24.52 \\
\hline No & 2968 & 75.48 \\
\hline \multicolumn{3}{|l|}{ Processing of concentrate fed } \\
\hline Soaked & 459 & 11.67 \\
\hline Cooked & 2727 & 69.35 \\
\hline Raw & 157 & 4.00 \\
\hline Soaked + Cooked & 689 & 17.52 \\
\hline \multicolumn{3}{|l|}{ Feeding of concentrates } \\
\hline Mixed with fodder & 2 & 0.05 \\
\hline Alone & 3930 & 99.95 \\
\hline \multicolumn{3}{|l|}{ Time of feeding concentrates } \\
\hline At time of milking & 3932 & 100.00 \\
\hline Other time & 00 & 0.00 \\
\hline \multicolumn{3}{|l|}{ Special feeding before calving } \\
\hline Yes & 3774 & 95.98 \\
\hline No & 158 & 4.02 \\
\hline \multicolumn{3}{|l|}{ Feeding of extra mineral mixture } \\
\hline Yes & 1219 & 31.00 \\
\hline No & 2713 & 69.00 \\
\hline \multicolumn{3}{|l|}{ Feeding of extra salt } \\
\hline 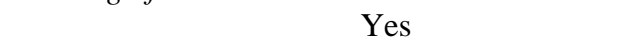 & 747 & 19.00 \\
\hline No & 3185 & 81.00 \\
\hline
\end{tabular}


Practice of concentrate feeding with cakes is not common in the area of survey. Readymade compound buffalo feed was provided by $24.52 \%$ of the farmers whereas $75.48 \%$ of the farmers provided only home produced ingredients as concentrate to fed their buffaloes. Home prepared concentrate mixture constituted crushed grain of barley mixed with oil cakes. These finding are in line with Bhuyan et al., (2004) and Garget al., (2005) and contrary to Singh et al., (2004). Regarding to pretreatment of concentrate mixture $69.35 \%$ of the respondents cooked concentrate mixture followed by soaking and cooking concentrate mixture before feeding.

All most $100 \%$ of respondents were feeding (Table 2) concentrate to lactating buffaloes at the time of milking. Only $0.05 \%$ of the farmers fed concentrate mixture mixed with fodder. The data of concentrate feeding to advanced pregnant buffalo was encouraging i.e. $95.98 \%$ of the respondents were feeding concentrate mixture as a special ration to advanced pregnant buffaloes which are essential because green fodder availability round the year was very low and possibility of green fodder production throughout the year was also less. The present findings are encouraging than reported by Grag et al., (2005) and Kumar et al., (2006).

Only 31 and 19 percent of the respondents fed mineral mixture and common salt to their buffaloes, respectively, a finding in agreement with the reports of Malik et al., (2005), Kumar et al., (2006) and Nagalakshmi et al., (2007).

It can be concluded based on present study indicated that adoption of scientific housing and feeding management practices was poor in survey area. Majority of animal houses were open type and had kaccha floor, used earthen plates with thatched for roofing material supported on wooden poles. Pucca drainage facility of urine was found in only $1.01 \%$ of animal shed. Not a single farmer practiced for silage making. Mineral mixtures were provided by only $31 \%$ of farmers and only $19 \%$ respondents were provided salt to their buffaloes. There are few aspects where they followed management practices properly to certain extent but most of the housing and feeding practices needs to be improved a lot in this area.

\section{References}

Bainwad, D.V., Deshmukh, B.R., Thombre, B.M. and Chauhan, D.S. 2007. Feeding and management practices adopted by buffalo farmers under watershed area. Indian $J$. Ani. Res., 41(1): 68-70.

Bhayan, R., Medhi, D., Konwar, B.K. and Saikia, B.N. 2004. An appraisal of feeding practices in the hill agro-climatic zone of Assam. Indian J. Ani. Nutri., 21(2): 137-39.

Chowdhary, N.R., Patel, J.B. and Bhakat, M. 2006. An overview of feeding, breeding and housing practices of dairy animals under milk co-operative system in Banaskantha district of North Gujarat region. Dairy Planner, 5(12): 8-10.

Gadariya, M.R., Dutta, K.S., Gadariya, H.B., Tanjne, K.R., Murth, K.S. and Gajbhiya, P.U. 2007. Breeding, health and housing management practices adopted for Gir cattle in their home-tract National symposium on recent treads in policy initiative and technological intervention for rural prosperity in small holder livestock production systems, Tirupati. 20-22 June 2007, p. 124.

Garg, M.K., Jain, L.S. and Chaudhary, J.L. 2005. Studies on housing,feeding and milking management practices of dairy cattle inBaran district of Rajasthan. Indian $J$. Dairy Sci., 58(2): 123-28.

Kalyankar, S.D., Chavan, C.D., Khedkar, C.D. and Kalyankar, S.P. 2008. Studies on management practices of buffaloes in different agro-climatic zones of Maharashtra. Indian J. Ani. Res., 42(3): 157-63.

Kumar, U., Mehla, R.K., Chandra, R. and Roy, B. 
2006. Studies on managemental practices followed by the traditional owners of Sahiwal cows in Punjab. Indian J. Dairy Sci., 58(2): 123-28.

Kushwaha, B.P., Kundu, S.S., Kumar, A., Maity, S.B. and Singh, S. 2007. Status of Bhadawari breed of buffalo in its breeding tract and its conservation. Indian J. Ani. Sci., 77(12): 1293-97.

Malik, B.S., Meena, B.S. and Rao, S.V.N. 2005. Study of existing dairy farming practices in Uttar Pradesh. J. Dairying, Foods and H.S., 24(2): 91-95.

Modi, R.J. 2003. 'Study of dairy animal management practices in Sabarkantha district of North Gujarat.' M.V.Sc. Thesis. Sardarkrushinagar Dantiwada Agricultural University, Sardarkrushinagar.

Nagalaksmi, D., Narsimha Reddy, D., Rajendra Prasad, M. and Pavani, P. 2007. Feeding practices and nutritional status of dairy animalsin Krishna-Godavari zone of Andhra Pradesh. National symposium on Recent trends in policy initiative and technological interventions for rural prosperity in small holder livestock production systems Tirupati, 20-22 June 2007. pp. 117-18.

Patel, J.B., Patel, N.B., Prajapti, K.B. and Brahmxatri, K.G. 2005. Animal husbandry practices for dairy animals in semi- arid region of Patan district. National seminar on 'Recent advances in conservation of Biodiversity and augmentation of reproduction and production in farm animals', pp 253, held 5-7 March, 2005 at Sardar Krushinagar Dantiwada Agricultural University, Sardar Krushinagar.

Sahu, S.P. 2001. 'The buffalo management practices followed by the farmers of Karnal and Kurukshetra district of Haryana, M.V.Sc. Thesis Haryana Agricultural University, Hisar.

Singh Parasu Ram, Singh, M., Jaiswal, R.S. and Raikwar Rakesh. 2004. Feeding of existing concentrate mixture dairy animal in the Kumaon hills of Uttaranchal. Indian J. Ani. Res., 38(2): 147-149.

Singh, M., Chauhan, A., Chand, S. and Garg, M.K. 2007b. Studies on housing and health care management practices followed by the dairy owners. Indian J. Ani. Res., 41(2): 79-86.

Sinha, R.R.K., Dutt, T., Singh, R.R., Bhushan, Bharat, Singh Mukesh and Kumar Sanjay. 2009. Feeding and housing management practices of dairy animals in Uttar Pradesh. Indian J. Ani. Sci., 79(8): 829-33.

Swaroop Devendra and Prasad Jagdish. 2007. Feeding systems ofdairy cattle and buffaloes in rural areas of Trans- Yamuna, Allahabad district. National symposium on recent trends in policy initiative and technological interventions for rural prosperity in small holder livestock production systems. Tirupati, 20-22 June 2007. pp. 75-76.

\section{How to cite this article:}

Parsant Jatolia, Suresh Chandra Jingar, Shiv Murat Meena, Pankaj Lawania, H.L. Bugaliya and Deelip Kumar. 2017. Existing Management Practices of Buffaloes Owners in Udaipur District of Rajasthan, India. Int.J.Curr.Microbiol.App.Sci. 6(8): 2103-2108. doi: https://doi.org/10.20546/ijcmas.2017.608.250 